\title{
Determinants of Oil Demand in OECD Countries: An Application of Panel Data Model
}

\author{
Burcu OZCAN ${ }^{*}$
}

\begin{abstract}
This study aimed to analyze demand for oil in 20 selected OECD countries over the period 1980 to 2011, within the framework of panel data model. The long-run income and price elasticities of oil demand were computed and the Granger causality between variables of interest was tested. The results indicated that oil demand has positive and negative income and price elasticities, respectively. In addition, both income and price were inelastic in the long-run, but price elasticity was lower than income elasticity. Furthermore, a bidirectional causality running from economic growth to oil consumption and vice versa was obtained, providing evidence of feedback hypothesis. Based on these results, some crucial policy implications were suggested.
\end{abstract}

Keywords: Oil Demand, Energy, Income Elasticity, Price Elasticity, Panel Data Model JEL Code Classification: C23, 013, Q41

UDC: 339.133.017: 339.923

\footnotetext{
${ }^{*}$ Faculty of Economics and Administrative Sciences, Firat University, Elazig, Turkey. E-mail: bozcan@firat.edu.tr
} 


\section{Introduction}

Energy is accepted as a crucial determinant of economic development and prosperity. Energy demand is expected to increase in the coming years, and today more than half of energy demand is satisfied by oil and natural gas (World Petroleum 2013). Though renewables are growing rapidly, fossil fuels remain the principal source of energy. About $80 \%$ of the global primary energy supply is made up of fossil fuels since the mid-1900s (World Energy Council 2013). As stated by Cooper (2003), crude oil, accounting for about $40.6 \%$ of primary energy consumption, has a preeminent position at the heart of the world economy and is the most important source of energy on the planet. As such, oil has a crucial role in the economic development process as an important strategic material and a highquality energy source (Xiong and Wu, 2008). More than any other energy resource, oil has powered the great economic boom of the past century and continues to drive the global economy (Tsirimokos, 2011).

Based on these explanations, modeling of energy demand, especially of oil, has been an important issue in the current context of energy insecurity and global warming (Lee and Chiu, 2013). As such, the studies of demand for oil products have attracted a great deal of attention since the two global oil shocks of 1973 and 1979 (Sa'ad, 2009). The pressure of volatile crude oil prices and environmental issues derived from the substitution of renewable energy sources for fossil-based ones reinforce this trend (Pedregal et al., 2009). In other words, due to recent hikes in oil prices and the search for alternative energy types, modeling determinants of oil consumption has turned out to be a crucial issue (Narayan \& Wong 2009).

In this context, modeling demand for oil (i.e., searching for its income and price elasticities), provides useful information to policy makers. First, to gauge the speed and degree of consumer reaction to changes in income and fuel prices, and to prescribe policies aimed at protecting the environment, are the major concerns of energy demand studies (Al-Faris, 1996). Second, as stated by Lee and Lee (2010) and Narayan and Smyth (2007), in projecting the future demand for oil and planning the required capacity to meet future domestic consumption, having accurate information on income and price elasticities is important. Third, the estimation of price and income elasticities of oil demand is essential in designing policies concerned with negative environmental externalities of the energy sector and in implementing more informed and successful energy policies (Iwayemi et al., 2010). Finally, accurate knowledge about income and price elasticities offers policy makers a guideline for the levels to which oil prices should be increased to reduce domestic consumption and pinpoints the potential for the market to realize energy conservation objectives (Al-Faris, 1996; Lee and Lee, 2010; Al-Yousef, 2013).

Given these considerations, the purpose of this study is to extend existing literature by examining the demand for oil in 20 selected OECD countries by taking slope heterogeneity and cross-sectional dependence issues into account in a panel data 
framework. We contribute to the existing literature in two aspects. First, we employ a panel data framework; as Narayan and Smyth (2007) note, even though most studies have confirmed that panel-based tests have higher power than tests based on individual series, there are few studies that have estimated income and price elasticities for energy within a panel data framework. As such, there are only two panel studies, Behmiri and Manso (2012) and Cho et al. (2011) which employ panel unit root and cointegration tests to estimate demand for oil in OECD countries. Second, we differ from them by taking cross-sectional dependence and slope heterogeneity issues into account in the estimation process; therefore, we employ different and recently developed panel unit root and cointegration tests suggested by Pesaran (2007) and Westerlund (2008), respectively.

The remainder of this paper is organized as follows: Sub-section 1.1 provides an overview of oil demand in OECD countries. In section 2, we provide a literature review. Data, model and methodology are explained in section 3 , while empirical results and discussion are presented in section 4 . Finally in section 5 , we end up study with policy implications.

\subsection{An Overview of Oil Consumption in OECD}

Oil demand has risen in several emerging and developing countries owing to fastgrowing gross domestic product (GDP) per capita and strong population growth. Over the decade to 2010 , world demand for oil rose by approximately $14 \%$. NonOECD countries fully accounted for this increase, whereas demand in OECD countries sharply fell (Fournier et al. 2013). In other words, there has been a significant change in the global energy map. While OECD countries were responsible for more than three-quarters of oil consumption in 1974, they are expected to be responsible for less than half soon (World Petroleum, 2013). Therefore, it could be stated that the center of gravity of energy demand is switching to emerging economies such as China, India, and the Middle East, which have driven global energy demand one-third higher (IEA, 2013). Though this trend, an average person from OECD countries consumes three tons of oil equivalent of energy (toe) a year, while the value is well below one toe in low-income regions such as Africa, most parts of Asia, and Latin America (OECD, 2012). Nevertheless, the share of oil in the energy consumption of OECD countries is on a declining trend. Oil consumption growth is mainly driven by non-OECD countries such as China (+8 million barrels per day $(\mathrm{Mb} / \mathrm{d})$ ), India $(+3.5 \mathrm{Mb} / \mathrm{d})$, and the Middle East $(+4$ $\mathrm{Mb} / \mathrm{d})$, whereas OECD oil consumption was expected to decline by $6 \mathrm{Mb} / \mathrm{d}$ after it peaked in 2005 (BP, 2012).

The reasons for this significant shift in the fuel mix of OECD are the changes in relative fuel prices, technological innovation, and policy interventions. In addition, renewable sources displace oil in transport and coal in power generation (BP, 2012). Furthermore, due to energy security and environmental concerns, oil intensity in OECD has begun to fall. As such, governments have attempted to curb 
oil demand via several tools such as fuel efficiency standards, removal of end-user subsidies, higher energy taxes, and supports for alternative energy sources such as biofuels and renewables (Fournier et al., 2013). Because nearly all OECD countries are also members of IEA (International Energy Agency), they pay special interest to curb $\mathrm{CO}_{2}$ emission levels. This situation necessitates the transformation of energy usage from fossil-based sources to renewables. As a result, non-OECD countries have the main responsibility for a $14 \%$ increase in global $\mathrm{CO}_{2}$ emissions, while the share of OECD in $\mathrm{CO}_{2}$ emissions from oil consumption is on a declining trend (Finley, 2012).

Figure 1 illustrates the time path of oil consumption across regions. There is an ongoing increase in oil consumption levels in the Asia-Pacific, Middle Eastern, and South and Central American regions. Although oil consumption level is the highest in the OECD region, it exhibits a decreasing trend over time. In addition, a sharp increase in oil consumption stands out for the Asia-Pacific regions, especially due to China and India.

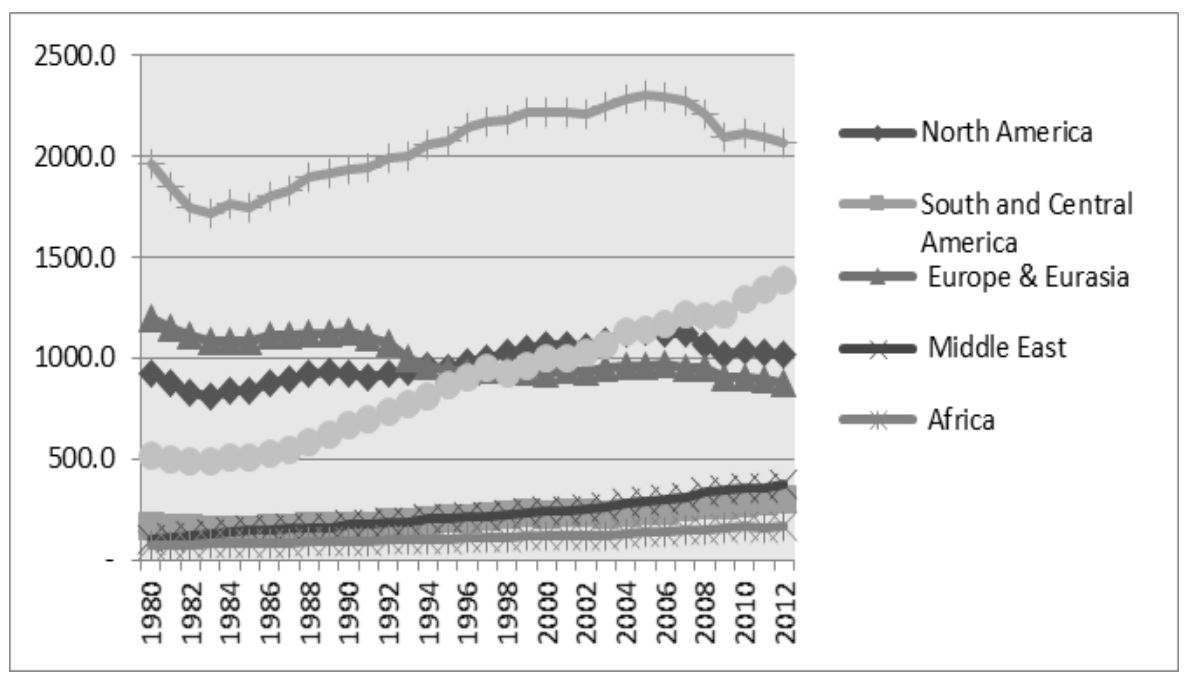

Figure 1: Million Tons Oil Consumption across Regions (1980-2012)

Source: British Petroleum Statictical Review of World Energy 2014.

\section{Literature Review}

There are a limited number of studies modeling demand for oil. ${ }^{1}$ In general, total energy demand is analyzed, but every type of energy has its own impact on the economy (Stambuli 2013). With regard to OECD countries, there are studies analyzing demand for different energy types such as electricity (see, among others,

\footnotetext{
${ }^{1}$ For an extensive literature review on energy demand seeDahl (1994) and Cho et al. (2011)
} 
Narayan - Smyth (2005) for Australia; Narayan et al. (2007) for G7; Halicioglu (2007) for Turkey; Lee - Lee (2010) for 25 OECD countries; Filippini (2011) for Sweden), natural gas (see, among others, Pindyck (1979) for OECD countries; Bilgili (2014) for OECD), and aggregate energy (see, among others, Dargay et al. (1992) for the UK; Lee and Lee (2010) for 25 OECD countries; and Lee and Chiu (2013) for 24 OECD countries).

In regard to oil demand, most studies apply time series analyses, while only few studies employ panel data models. As such, there are a number of time series studies based on an individual country or a group of countries. Some of them employ the autoregressive distributed lag ( $A R D L)$ bounds testing approach to cointegration developed by Pesaran et al. (2001) in modeling demand for crude or imported oil (see, among others, De Vita et al., 2006; Altinay, 2007; Ghosh, 2009; Moore, 2011). In addition to the ARDL approach, other time series cointegration tests are also employed to estimate demand for oil (see, among others, Krichene (2002, 2005) for world markets; Dees et al. (2007) for 10 main trading partners of the euro area; Xiong and Wu (2008) for China; Ziramba (2010) for South Africa; Sillah and Al-Sheikh (2012) for six Gulf Cooperation countries (GCC)).In addition, some studies employ lagged models such as the Koyck, Almon, and partial adjustment model (see, among others, Ghouri, 2001; Gately \& Huntington, 2002; Stambuli, 2013).

Additionally, there are a limited number of studies employing panel unit root and cointegration tests in modeling demand for oil. First, Narayan and Smyth (2007) estimated demand for oil in 12 Middle Eastern countries over the period 19712002. They found that long-run income and price elasticities ranged between 0.727 to 1.816 and -0.002 to -0.071 , respectively. The short-run income and price elasticities were 0.171 and -0.0008 (not significant), respectively. Second, Narayan and Wong (2009) evaluated the determinants of oil consumption for a panel consisting of six Australian states and one territory for the period 1985-2006 and found that long-run income elasticity was 0.17 , while long-run price elasticity was 0.02 (insignificant). Last, Fawcett and Price (2012) evaluated oil demand in a panel consisting of 53 countries (as in the four groups: G7, rest of OECD, developing Asia, and Latin America) and obtained different results for each country group.

With respect to the OECD sample, demand for crude oil was modeled by some studies for only one country or a group of countries. Most of them, however, used time series data instead of panel data. For instance, applying Nerlove's partial adjustment model, Cooper (2003) estimated the short- and long-run price elasticities of demand for crude oil in 23 OECD countries. Additionally, Tsirimokos (2011), through an adaption of Nerlove's partial adjustment model, estimated demand for crude oil for 10 IEA and OECD member countries. But there are only two studies applying panel cointegration and panel unit root tests in modeling demand for oil in OECD countries. First, Behmiri and Manso (2012) aimed to define the causal relationship between GDP and oil consumption for 27 OECD countries 
over the period of 1976 to 2009. They also computed the long-run price and income elasticities of demand for oil, though they did not clearly state this in their study. Second, Cho et al. (2011) analyzed the demand for crude oil for 25 OECD countries, 14 Asian countries, and 12 other countries for the period of 1971-2005.

To conserve space, we cannot explain detailed methods and results of oil demand studies. In Table 1, however, we provide the detailed results of studies in the literature. In addition, the results of studies about OECD countries are explained in the subsection on empirical results for comparison purposes. Based on the findings of studies reported in Table 1, it can be asserted that the price elasticity of demand for oil is generally inelastic, whereas income elasticity is either around unity or inelastic.

Table 1: A Summary of Literature Review

\begin{tabular}{|c|c|c|c|c|c|c|c|}
\hline Study & Country & Period & Method & \begin{tabular}{|c|} 
LR-income \\
elasticity
\end{tabular} & $\begin{array}{l}\text { LR-price } \\
\text { elasticity }\end{array}$ & \begin{tabular}{|c|}
$\begin{array}{c}\text { SR-income } \\
\text { elasticity }\end{array}$ \\
\end{tabular} & $\begin{array}{l}\text { SR-price } \\
\text { elasticity }\end{array}$ \\
\hline \begin{tabular}{|l|} 
Altinay \\
$(2007)$
\end{tabular} & Turkey & 1980-2005 & ARDL & 0.61 & -0.18 & 0.64 & -0.10 \\
\hline \begin{tabular}{|l|} 
Behmiri \\
and Manso \\
$(2012)$
\end{tabular} & $\begin{array}{l}27 \text { OECD } \\
\text { countries }\end{array}$ & 1976-2009 & $\begin{array}{c}\text { Panel } \\
\text { cointegration } \\
\text { tests and } \\
\text { FMOLS } \\
\end{array}$ & -0.42 to 2.5 & $\begin{array}{l}-0.23 \text { to } \\
+0.09\end{array}$ & & \\
\hline $\begin{array}{l}\text { Cho et al. } \\
(2011)\end{array}$ & 51 countries & 1971-2005 & \begin{tabular}{c|} 
Panel \\
cointegration \\
tests and \\
FMOLS \\
\end{tabular} & $\begin{array}{c}0.37 \text { (all) } \\
0.44 \text { (Asia) } \\
0.06(\mathrm{OECD})\end{array}$ & $\begin{array}{c}-0.01 \text { (all) } \\
-0.03 \text { (Asia) } \\
-0.02 \\
\text { (OECD) }\end{array}$ & ---- & ----- \\
\hline $\begin{array}{l}\text { Cooper } \\
(2002)\end{array}$ & $\begin{array}{l}23 \text { OECD } \\
\text { countries }\end{array}$ & $1971-2000$ & $\begin{array}{c}\text { OLS } \\
\text { (Nerlove's } \\
\text { partial } \\
\text { adjustment } \\
\text { model) }\end{array}$ & ---- & $\begin{array}{l}0.005 \text { to } \\
-0.568\end{array}$ & --- & $\begin{array}{c}0.001 \text { to } \\
-0.109\end{array}$ \\
\hline \begin{tabular}{|l|} 
Dees et al. \\
$(2007)$
\end{tabular} & $\begin{array}{l}10 \text { main } \\
\text { trading } \\
\text { partners of the } \\
\text { euro area }\end{array}$ & 1984- 2002 & $\begin{array}{l}\text { DOLS and } \\
\text { VECM }\end{array}$ & 0.17 to 0.98 & ----- & 0.01 to 0.82 & $\begin{array}{l}-0.07 \text { to } \\
-0.03\end{array}$ \\
\hline $\begin{array}{l}\text { De vita et } \\
\text { al. (2006) }\end{array}$ & Namibia & \begin{tabular}{|l|}
$1980-2002$ \\
$1990-2002$ \\
\end{tabular} & ARDL & $\begin{array}{l}1.08 \\
0.95 \\
\end{array}$ & $\begin{array}{l}-0.85 \\
-0.79 \\
\end{array}$ & ----- & ----- \\
\hline $\begin{array}{l}\text { Fawcett } \\
\text { and Price } \\
(2012)\end{array}$ & $\begin{array}{l}* \text { G7 } \\
* \text { Remaining } \\
\text { OECD } \\
\text { *Developing } \\
\text { Asia } \\
\text { *Latin America }\end{array}$ & & $\begin{array}{c}\text { Panel unit } \\
\text { root and } \\
\text { cointegration } \\
\text { tests }\end{array}$ & 0.26 to 1.31 & $\begin{array}{c}-0.15 \text { to } \\
-0.06\end{array}$ & 0.61 to 0.90 & $\begin{array}{c}-0.04 \text { to } \\
0.008\end{array}$ \\
\hline \begin{tabular}{|l|} 
Gately and \\
Huntingto \\
$\mathrm{n}(2002)$ \\
\end{tabular} & $\begin{array}{l}96 \text { OECD non- } \\
\text { OECD }\end{array}$ & 1971-1997 & $\begin{array}{c}\text { Panel fixed } \\
\text { effects model }\end{array}$ & $\begin{array}{l}0.55 \\
0.95\end{array}$ & $\begin{array}{l}-0.60 \\
-0.12\end{array}$ & --- & ---- \\
\hline $\begin{array}{l}\text { Ghosh } \\
(2009)\end{array}$ & India & \begin{tabular}{|c|}
$1970-71$ to \\
$2005-06$ \\
\end{tabular} & ARDL & 1.97 & $-0.63^{n}$ & --- & ---- \\
\hline $\begin{array}{l}\text { Ghouri } \\
(2001)\end{array}$ & $\begin{array}{l}\text { US } \\
\text { Canada Mexico }\end{array}$ & 1980-1999 & Almon model & $\begin{array}{l}0.98 \\
1.08 \\
0.84\end{array}$ & $\begin{array}{l}-0.045 \\
-0.06 \\
-0.13\end{array}$ & --- & $\begin{array}{l}-0.029 \\
-0.007 \\
-0.015\end{array}$ \\
\hline
\end{tabular}


Determinants of Oil Demand in OECD Countries: An Application of Panel Data Model

Table 1 (cont.): A Summary of Literature Review

\begin{tabular}{|c|c|c|c|c|c|c|c|}
\hline Study & Country & Period & Method & $\begin{array}{l}\text { LR-income } \\
\text { elasticity }\end{array}$ & $\begin{array}{l}\text { LR-price } \\
\text { elasticity }\end{array}$ & $\begin{array}{c}\text { SR-income } \\
\text { elasticity }\end{array}$ & $\begin{array}{l}\text { SR-price } \\
\text { elasticity }\end{array}$ \\
\hline $\begin{array}{l}\text { Krichene } \\
(2005)\end{array}$ & World market & \begin{tabular}{|l|}
$1918-2004$ \\
$1918-1973$ \\
$1974-2004$ \\
\end{tabular} & \begin{tabular}{|c|} 
Cointegration \\
and two-stage \\
least squares \\
\end{tabular} & $\begin{array}{l}3.48 \\
3.43 \\
0.62 \\
\end{array}$ & $\begin{array}{l}-1.59 \\
-2.73 \\
-012 \\
\end{array}$ & $\begin{array}{l}0.54 \\
0.43 \\
1.49 \\
\end{array}$ & $\begin{array}{c}-0.05 \\
-0.05 \\
-0.003 \\
\end{array}$ \\
\hline \begin{tabular}{|l|} 
Moore \\
$(2011)$ \\
\end{tabular} & Barbados & 1998- 2009 & ARDL & 0.91 & -0.55 & ---- & ----- \\
\hline \begin{tabular}{|l|} 
Narayan \\
and Smyth \\
$(2007)$
\end{tabular} & $\begin{array}{l}12 \text { Middle East } \\
\text { countries }\end{array}$ & 1971- 2002 & $\begin{array}{l}\text { Panel cointe- } \\
\text { gration tests } \\
\text { and DOLS }\end{array}$ & 1.014 & -0.015 & 0.1715 & $-0.0008^{n}$ \\
\hline $\begin{array}{l}\text { Narayan } \\
\text { and Wong } \\
(2009)\end{array}$ & \begin{tabular}{|l} 
6Australian \\
States and one \\
territory
\end{tabular} & 1985-2006 & \begin{tabular}{|c|} 
Panel \\
cointegration \\
tests and \\
FMOLS \\
\end{tabular} & 0.17 & $0.02^{n}$ & ----- & ----- \\
\hline \begin{tabular}{|l} 
Sillah and \\
Al-Sheikh \\
$(2012)$ \\
\end{tabular} & $\operatorname{six}$ GCC & $1980-2010$ & $\begin{array}{c}\text { Cointegration } \\
\text { and VECM }\end{array}$ & $\begin{array}{l}-2.20 \text { to } \\
+0.28\end{array}$ & $\begin{array}{c}-0.30 \text { to } \\
2.51\end{array}$ & ---- & ------ \\
\hline $\begin{array}{l}\text { Stambuli } \\
\text { (2013) }\end{array}$ & Tanzania & 1972- 2010 & \begin{tabular}{|c|} 
Nerlove's \\
Partial \\
Adjustment \\
Model (PAM) \\
\end{tabular} & 1.750 & -0.012 & 0.747 & -0.005 \\
\hline $\begin{array}{l}\text { Tsirimokos } \\
(2011)\end{array}$ & $\begin{array}{l}10 \text { IEA } \\
\text { member- } \\
\text { countries }\end{array}$ & 1980-2009 & \begin{tabular}{|c|} 
Nerlove's \\
partial adjust- \\
tment model \\
\end{tabular} & $\begin{array}{c}0.726 \text { to } \\
2.473\end{array}$ & $\begin{array}{l}-0.275 \text { to } \\
-0.066\end{array}$ & $\begin{array}{c}0.355 \text { to } \\
0.66\end{array}$ & $\begin{array}{c}-0.104 \text { to }- \\
0.036\end{array}$ \\
\hline \begin{tabular}{|l|} 
Xiong and \\
Wu (2008) \\
\end{tabular} & China & 1979-2004 & $\begin{array}{c}\text { Johansen and } \\
\text { VECM }\end{array}$ & 0.647 & -0.365 & --- & ---- \\
\hline \begin{tabular}{|l|} 
Ziramba \\
$(2010)$ \\
\end{tabular} & South Africa & 1980-2006 & $\begin{array}{c}\text { Johansen and } \\
\text { VECM }\end{array}$ & 0.429 & -0.147 & $0.206^{n}$ & $0.046^{n}$ \\
\hline \begin{tabular}{|l|} 
Ghosh \\
$(2009)$ \\
\end{tabular} & India & \begin{tabular}{|c|}
$1970-71$ to \\
$2005-06$ \\
\end{tabular} & ARDL & 1.97 & $-0.63^{n}$ & --- & ---- \\
\hline $\begin{array}{l}\text { Ghouri } \\
(2001)\end{array}$ & $\begin{array}{l}\text { US } \\
\text { Canada Mexico }\end{array}$ & 1980-1999 & Almon model & $\begin{array}{l}0.98 \\
1.08 \\
0.84 \\
\end{array}$ & $\begin{array}{l}-0.045 \\
-0.06 \\
-0.13 \\
\end{array}$ & --- & $\begin{array}{l}-0.029 \\
-0.007 \\
-0.015 \\
\end{array}$ \\
\hline
\end{tabular}

Notes: VECM represents error correction model; ${ }^{n}$ denotes insignificance; LR and SR indicate long-run and short-run, respectively; $A R D L$ is the autoregressive distributed lag model; FMOLS is the fully modified ordinary least squares; DOLS is the dynamic ordinary least squares.

\section{Methodology}

\subsection{Model and Data}

We use a log-linear specification that is widely used in energy demand modeling because it provides more robust and reliable results than a simple linear specification. In addition, based on the other studies in the literature (see, among others, (Altinay, 2007; Narayan \& Smyth 2007; Narayan \& Wong 2009; Lee \& Lee, 2010) and on the Marshallian theory of demand for goods and services, we use a simple energy demand model consisting of the oil's own price and per capita income level. Though there are many other effective factors on consumer demand, such as taste and consumer preferences, lifestyle, the prices of substitutes and 
complements, and technological innovation, it is difficult to quantify and measure them (Mitchell, 2006). Thus, oil or energy consumption is basically treated as a positive function of real income and a negative function of own price (Narayan \& Smyth 2007). Furthermore, as indicated by Altinay (2007), crude oil is not a final good and is different from the other energy sources, since it is not directly consumed. Yet, because its derivatives are used in many different areas, it is ideal to define the demand for crude oil in a straightforward way.

We use per capita crude oil consumption measured in thousands of barrel per day. Crude oil consumption data are from the British Petroleum Statistical Review of World Energy (2014) and were divided by population derived from the World Development Indicators (2014) to calculate the per capita oil consumption. As a proxy for income level, per capita real GDP in constant 2005 US dollars from the World Development Indicators was used. As indicated by Narayan and Smyth (2007), the real per capita income may be seen as accommodating structural change in the model. In addition, real oil price was defined as the US dollar price of oil converted to domestic currency and then deflated by the domestic consumer price index (CPI). The nominal Brent crude oil price in US dollars per barrel and the CPI were obtained from International Financial Statistics (2014) published by the International Monetary Fund (IMF), while exchange rate data in national currency/US dollar are from the Penn World Table (PWT 8.0) (2013). We converted all data into natural logarithmic form prior to conducting the analysis and defined the model in Eq. (1):

$$
\ln O C_{i t}=\beta_{0 i}+\beta_{1 i} \ln Y_{i t}+\beta_{2 i} \ln O P_{i t}+\varepsilon_{i t}
$$

where the per capita oil consumption $\left(O C_{i t}\right)$ is a function of per capita real GDP $\left(Y_{i t}\right)$ and real oil price $\left(O P_{i t}\right)$. The subscripts $i$ and $t$ represent cross-section and time dimensions, respectively, while $\varepsilon_{i t}$ is the error term assumed to be independently and normally distributed. The coefficients $\beta_{1}$ and $\beta_{2}$ are the income and price elasticities of oil consumption, respectively. The sign of $\beta_{1}$ is generally expected to be positive, because it is expected that a higher per capita income level leads to increases in oil consumption. As indicated by Farrinelli et al. (2009), however, if oil is considered an inferior good instead of a normal good, $\beta_{1}$ may be negative, since increases in income level may direct some developed OECD countries to use alternative and eco-friendly energy sources such as renewable and nuclear energy sources. Concerning the sign of $\beta_{2}$, it is expected to be negative, as price is inversely related to quantity demanded. In addition, the price (income) is assumed to be inelastic if the degree of sensitivity of crude oil demand to price (income) is low; whereas if the changes in price and income lead to significant responses in oil demand, the demand for crude oil is accepted as elastic. 
Our sample includes the selected 20 OECD countries-namely, Austria, Belgium, Canada, Denmark, Finland, France, Germany, Iceland, Ireland, Italy, Japan, the Netherlands, Norway, Portugal, Spain, Sweden, Switzerland, Turkey, the United Kingdom (UK), and the United States (US). The time period is from 1980 to 2011, and the sample and time period were dictated by data availability.

\subsection{Cross-Sectional Dependence Test}

Before deciding on the right panel unit root and cointegration tests, we need to decide whether there is cross-sectional dependence among panel members. Due to globalization and international linkages, countries can transmit their shocks to each other. With this aim, we employed the Lagrange multiplier (LM) test, developed by Breusch and Pagan (1980) and appropriate in cases where the $T$ is relatively larger than $\mathrm{N}$ (as in our case). The null hypothesis of cross-sectional independence is $\boldsymbol{H}_{\mathrm{o}}: \operatorname{Cov}\left(\boldsymbol{u}_{i t}, \boldsymbol{u}_{j t}\right)=\mathbf{O}$, for all $t$ and $i \neq j$, is tested against the alternative hypothesis of cross-sectional dependence $\boldsymbol{H}_{1}: \operatorname{Cov}\left(\boldsymbol{u}_{i t}, \boldsymbol{u}_{j t}\right) \neq \mathrm{O}$ for at least one pair of $i \neq j$. The test is based on the following LM statistic:

$$
L M=T \sum_{i=1}^{N-1} \sum_{j=i+1}^{N} \hat{\rho}_{i j}
$$

where $\hat{\rho}_{i j}$ indicates a sample estimate of the pair-wise correlation of the residuals. Additionally, the LM statistic is asymptotically distributed as chi-squared with $N(N-1) / 2$ degrees of freedom. ${ }^{2}$

\subsection{Pesaran (2007) Unit Root Test}

Due to the presence of cross-sectional dependence, we decided to employ a second-generation panel unit root test, which is the cross-sectionally augmented version of IPS test developed by Im et al. (2003), suggested by Pesaran (2007). The test allows for cross-sectional dependence by introducing an unobserved single common factor to the regression equation.

In the test procedure, the standard augmented Dickey and Fuller (ADF hereafter, 1979) regressions are augmented with the cross-section averages of lagged levels and first differences of the individual series as follows (Tiwari et al., 2012):

$$
\Delta y_{i, t}=\alpha_{i}+b_{i} y_{i, t-1}+c_{i} \bar{y}_{t-1}+d_{i} \Delta \bar{y}_{i}+e_{i, t}
$$

\footnotetext{
${ }^{2}$ We also employed the bias-adjusted version of LM test developed by Pesaran et al. (2008). However, to conserve space, we didn't explain its methodology; however, an interested reader can refer to Pesaran et al. (2008)
} 
where $\alpha_{i}$ is a deterministic term; $b_{i}, c_{i}$, and $d_{i}$ are the slope coefficients estimated from the ADF test in country $i ; \bar{y}_{t-1}$ is the mean value of lagged levels and $\Delta \bar{y}_{i}$ is the mean value of first-differences; and $e_{i, t}$ is the error term. The test of unit root is based on the t-ratio of the OLS estimate of $b_{i}\left(\hat{b}_{i}\right)$. Pesaran (2007) suggested using the cross-sectional augmented IPS (CIPS) test statistic, $C I P S=N^{-1} \sum_{i=1}^{N} t_{i}(N, T)$, based on the average of individual cross-sectional ADF (CADF), where $t_{i}(N, T)$ is the CADF statistic for the $i$ th cross-section unit given by the t-ratio of $b_{i}$.

\subsection{Slope Homogeneity and Westerlund (2008) Cointegration Tests}

The next step is testing for homogeneity of slope coefficients in Eq. (1) to decide the right cointegration test. To this end, we implemented the Delta tests $\left(\tilde{\Delta}, \tilde{\Delta}_{\text {adj }}\right)$ defined in Pesaran and Yamagata (2008). There are four Delta tests $\left(\tilde{\Delta}, \tilde{\Delta}_{a d j}, \hat{\Delta}\right.$ and $\hat{\Delta}_{\text {adj }}$ ), but because Pesaran and Yamagata (2008) suggested that $\tilde{\Delta}$ tests are likely to have better size properties than $\hat{\Delta}$ tests, we employed $\tilde{\Delta}$ and $\tilde{\Delta}_{a d j}$ tests. The standardized dispersion statistics, $\tilde{\Delta}$ and $\tilde{\Delta}_{a d j}$, are defined by Eqs. (4) and (5):

$$
\widetilde{\Delta}=\sqrt{N}\left(\frac{N^{-1} \tilde{S}-k}{\sqrt{2 k}}\right)
$$

where $\mathrm{k}$ is the number of exogenous regressors, $\widetilde{S}$ is the Swamy's (1970) test statistic, and $N$ is the cross-section dimension. The small sample properties of the $\tilde{\Delta}$ test can be improved under the normally distributed errors by considering the following mean and variance bias adjusted version of $\tilde{\Delta}$ :

$$
\tilde{\Delta}_{a d j}=\sqrt{N}\left(\frac{N^{-1} \widetilde{S}-E\left(\widetilde{z}_{i T}\right)}{\sqrt{\operatorname{Var}\left(\tilde{z}_{i T}\right)}}\right)
$$

where $E\left(\tilde{z}_{i T}\right)=k$ and $\operatorname{Var}\left(\tilde{z}_{i T}\right)=\frac{2 k(T-k-1)}{T+1}$. 
The next step is testing for the long-run relationship among $O C_{i t}, Y_{i t}$, and $O P_{i t}$ defined in Eq. (1). For that purpose, we implemented the Durbin Hausman-group mean test (DHg), developed by Westerlund (2008), as we obtained evidence of slope heterogeneity.

Westerlund's (2008) test takes cross-sectional dependence into account through the use of common factors. In other words, the errors in Eq. (1) are obtained by innovations and unobservable common factors. The error terms in Eq. (1) are assumed to obey the following set of equations:

$$
\begin{aligned}
& \varepsilon_{i t}=\lambda_{i}^{\prime} F_{t}+e_{i t}, \\
& F_{j t}=\rho_{j} F_{j t-1}+u_{j t}, \\
& e_{i t}=\phi_{i} e_{i t-1}+v_{i t},
\end{aligned}
$$

where $F_{t}$ is a k-dimensional vector of common factors $F_{j t}$, while $\lambda_{i}$ is a conformable vector of factor loadings. The stationarity of $F_{t}$ is ensured by assuming that $\rho_{j} \prec 1$ for all $j$, indicating the integration order of the composite regression error $\varepsilon_{i t}$ depends only on the integratedness of the idiosyncratic disturbance $e_{i t}$. Therefore, in this data generation process, the long-run relationship defined in Eq. (1) is valid if $\phi_{i} \prec 0$.

Westerlund (2008) developed two cointegration tests-namely, panel ( $\left.D H_{p}\right)$ and group mean ( $\mathrm{DHg}$ ) statistics. $\mathrm{DH}_{p}$ is constructed under the assumption of $\hat{\phi}_{i}=\hat{\phi}$ for all $i$, whereas the $D H g$ test is not. Both tests are composed of two estimators of $\phi_{i}$ (i.e., ordinary least squares [OLS] and instrumental variable [IV] estimators). As such, $\widetilde{\phi}_{i}$ and $\tilde{\phi}$ are the individual and pooled IV estimators of $\phi_{i}$ obtained by instrumenting $\hat{e}_{i t-1}$ with $\hat{e}_{i t}$; whereas $\hat{\phi}_{i}$ and $\hat{\phi}$ are the individual and pooled OLS estimators of $\phi_{i}$. Both the OLS and IV estimators are used to construct the Durbin-Hausman tests. Then we can consider the following kernel estimator:

$$
\hat{\omega}_{i}^{2}=\frac{1}{T-1} \sum_{j=-M_{i}}^{M i}\left(1-\frac{j}{M_{i}+1}\right) \sum_{t=j+1}^{T} \hat{v}_{i t} \hat{v}_{i t-j}
$$

where $\hat{v}_{i t}$ indicates the residuals obtained via OLS from Eq. (8). The bandwidth 
parameter, $M_{i}$, defines how many autocovariances of $\hat{v}_{i t}$ are necessary to estimate in the kernel. The quantity $\hat{\omega}_{i}^{2}$ is a consistent estimate of the long-run variance of $v_{i t}\left(\omega_{i}^{2}\right)$. Thus, we can define two variance ratios, $\hat{S}_{i}=\hat{\omega}_{i}^{2} / \hat{\sigma}_{i}^{4}$ and $\hat{S}_{n}=\hat{\omega}_{n}{ }^{2} /\left(\hat{\sigma}_{n}{ }^{2}\right)^{2}$, where $\hat{\omega}_{n}{ }^{2}=\frac{1}{n} \sum_{i=1}^{n} \hat{\omega}_{i}^{2}, \hat{\sigma}_{n}^{2}=\frac{1}{n} \sum_{i=1}^{n} \hat{\sigma}_{i}^{2}$, and $\hat{\sigma}_{i}^{2}$ denotes the related contemporaneous variance estimate. We can define the $\mathrm{DH}$, and $\mathrm{DHg}$ test statistics as follows:

$$
\begin{aligned}
D H_{g} & =\sum_{i=1}^{n} \hat{S}_{i}\left(\tilde{\phi}_{i}-\hat{\phi}_{i}\right) \sum_{t=2}^{T} \hat{e}_{i t-1}^{2} \\
D H_{p} & =\hat{S}_{n}(\tilde{\phi}-\hat{\phi})^{2} \sum_{i=1}^{n} \sum_{t=2}^{T} \hat{e}_{i t-1}^{2}
\end{aligned}
$$

The main difference between these two statistics lies in the formulation of the alternative hypothesis. For the $D H_{p}$ test, the null hypothesis is $H_{0}: \phi_{i}=1$ for all $i=$ $1, \ldots \ldots \ldots, n$ against the alternative hypothesis, $H_{1}^{p}: \phi_{i}=\phi$ and $\phi \prec 1$ for all $i$. In this case, a common autoregressive parameter value is assumed under both the null and the alternative hypotheses. Therefore, in case of rejection of the null hypothesis, the cointegration does hold for all $n$ units. By contrast, with respect to the $\mathrm{DHg}$ test, $H_{0}$ is tested versus the alternative hypothesis $H_{1}^{g}: \phi_{i} \prec 1$ for at least some $i$. In this case, a common value for the autoregressive parameter is not assumed; therefore, rejection of the null hypothesis implies that there is cointegration only for some of the panel members.

\subsection{Heterogeneous Panel FMOLS Estimator}

In this study, we used the panel-based fully modified ordinary least squares (FMOLS) estimator suggested by Pedroni (2001a) to obtain long-run coefficients in Eq. (1). We used time-demeaned data because the FMOLS estimator does not take cross-sectional dependence into account. ${ }^{3}$ The FMOLS estimator provides consistent and efficient estimations for the long-run relationship because it corrects for both the endogeneity bias and serial correlation. The panel FMOLS estimator has three versions: the residual-FM, the adjusted-FM, and the group-FM. The first two estimators pool the data along the within-dimensions, while the

\footnotetext{
${ }^{3}$ The following form is obtained via demeaning: $\left(y_{i t}-\bar{y}\right)=\left(\alpha_{i}-\bar{\alpha}\right)+\theta^{\prime}\left(x_{i t}-\bar{x}_{t}\right)+\left(\mu_{i t}-\bar{\mu}_{t}\right)$, where $\left(\bar{y}_{t}=\frac{1}{N} \sum_{i}^{N} y_{i t}\right)$ and where $y, \alpha, x$, and $\mu$ represent the dependent variable, fixed effects, independent variables, and the error term, respectively.
} 
group-FM estimator pools the data along the between-dimension (Pedroni, 2001b). Because the slope homogeneity tests provided evidence of heterogeneity in the cointegrating vector, we employed the group-FM estimator, which allows for greater flexibility in the presence of heterogeneity in the cointegrating vectors. The null hypothesis for the group-FM estimator is $H_{0}: \beta_{i}=\beta_{0}$ for all $i$ against the alternative hypothesis $H_{1}: \beta_{i} \neq \beta_{0}$, where the parameters of $\beta_{i}$ in Eq. (1) are not required to be the same under the $H_{1}$. The group-FM estimator can be constructed as $\hat{\beta}^{*}{ }_{G F M}=N^{-1} \sum_{i=1}^{N} \hat{\beta}_{F M_{i}}^{*}$, where $\beta_{F M_{i}}^{*}$ represents time series FMOLS estimation of Eq. (1) for each cross-section unit.

\subsection{Panel Causality Test}

Following the two steps of Engle and Granger (1987) to expose Granger causality among the variables in both the long-run and short-run, we employed a panelbased vector error-correction (PVEC) model. To this end, we first estimated Eq. (1) through the FMOLS estimator and obtained the residuals to define the first-lagged residuals as the error-correction term. We then estimated the following dynamic error-correction models $(12 a-12 c)$ through the pooled mean group (PMG) estimator proposed by Pesaran et al. (1999). In general, the GMM estimator, developed by Arellano - Bond (1991), is used in panel causality tests. However, the GMM estimator requires pooling of individuals and allows only the intercepts to differ across countries. However, the PMG estimator allows for variation in intercept, slope coefficients, and error variance across cross-sectional units, and therefore takes heterogeneity among cross-section members of the panel into account. The PMG estimator, however, does not allow for cross-sectional dependence. Therefore, we transform the variables by time demeaning the data (see Salim et al. 2014).

$$
\begin{aligned}
& \Delta O C_{i t}=\alpha_{1 i}+\sum_{k=1}^{m} \theta_{11 i k} \Delta O C_{i t-k}+\sum_{k=1}^{m} \theta_{12 i k} \Delta Y_{i t-k}+\sum_{k=1}^{m} \theta_{13 i k} \Delta O P_{i t-k}+\gamma_{1 i} E C T_{i t-1}+u_{1 i t} \\
& \Delta O P_{i t}=\alpha_{2 i}+\sum_{k=1}^{m} \theta_{21 i k} \Delta O P_{i t-k}+\sum_{k=1}^{m} \theta_{22 i k} \Delta Y_{i t-k}+\sum_{k=1}^{m} \theta_{23 i k} \Delta O C_{i t-k}+\gamma_{2 i} E C T_{i t-1}+u_{2 i t} \\
& \Delta Y_{i t}=\alpha_{3 i}+\sum_{k=1}^{m} \theta_{31 i k} \Delta Y_{i t-k}+\sum_{k=1}^{m} \theta_{32 i k} \Delta O C_{i t-k}+\sum_{k=1}^{m} \theta_{33 i k} \Delta O P_{i t-k}+\gamma_{3 i} E C T_{i t-1}+u_{3 i t}
\end{aligned}
$$

where the term $\Delta$ indicates the first differences and $m$ is the lag length set at 1 , which is based on the Schwarz information criterion. The variables in logarithmic differences refer to growth rates of variables of interest. ECT represents the errorcorrection term, $\gamma_{j i}(j=1,2,3)$ is the adjustment coefficient, and $u_{j i}$ is the disturbance term, assumed to be uncorrelated with zero means. With respect to Eqs. (12a)-(12c), the short-run causality is defined by the significance of 
$\chi^{2}$ statistics of the related independent variables, while the long-run causality is determined by using a t-test for the statistical significance of the respective errorcorrection terms.

In terms of short-run causality represented in Eq. (12a), causality runs from $\Delta Y$ to $\triangle O C$ if the null hypothesis $\theta_{12 i k}=0 \forall_{i k}$ is rejected, while causality runs from $\triangle O P$ to $\triangle O C$ if the null hypothesis $\theta_{13 i k}=0 \forall_{i k}$ is rejected via a Wald test. With respect to Eq. (12b), the short-run causality runs from $\Delta Y$ to $\triangle O P$ if $\theta_{22 i k}=0 \forall_{i k}$ is rejected, whereas causality runs from $\triangle O C$ to $\triangle O P$ if $\theta_{23 i k}=0 \forall_{i k}$ is rejected. In Eq. (12c), short-run causality runs from $\triangle O C$ to $\Delta Y$ if $\theta_{32 i k}=0 \forall_{i k}$ is rejected, whereas causality runs from $\triangle O P$ to $\Delta Y$ if $\theta_{33 i k}=0 \forall_{i k}$ is rejected. Regarding the long-run causality represented in Eq. (12a), if the null hypothesis $\gamma_{1 i}=0 \forall_{i}$ is rejected, then $\triangle O C$ responds to deviations from long-run equilibrium. In Eq. (12b), if the null hypothesis $\gamma_{2 i}=0 \forall_{i}$ is rejected, then $\triangle O P$ responds to deviations from long-run equilibrium. Finally, in Eq. (12c), if the null hypothesis $\gamma_{3 i}=0 \forall_{i}$ is rejected, $\Delta Y$ responds to deviations from long-run equilibrium.

\section{Results and Discussion}

\subsection{Results of Cross-Sectional Dependence and Pesaran (2007) Unit Root Tests}

To decide which unit root test is appropriate for our estimation, we implemented the LM test developed by Breusch and Pagan (1980) for both the model and each variable. The results are presented in Table 2, which also notes the results of the bias-adjusted LM test of Pesaran et al. (2008).

Table 2: Results of Cross-Sectional Dependence Test

\begin{tabular}{|c|c|c|}
\hline Variables & LM Test & Bias-Adjusted LM Test \\
\hline \multirow{2}{*}{$O C_{i t}$} & $314.732^{\mathrm{a}}$ & $1.407^{\mathrm{c}}$ \\
& $(0.000)$ & $(0.080)$ \\
\hline \multirow{2}{*}{$O P_{i t}$} & $855.796^{\mathrm{a}}$ & $107.567^{\mathrm{a}}$ \\
& $(0.000)$ & $(0.000)$ \\
\hline \multirow{2}{*}{$Y_{i t}$} & $410.708^{\mathrm{a}}$ & $96.147^{\mathrm{a}}$ \\
& $(0.000)$ & $(0.000)$ \\
\hline \multirow{2}{*}{ Model } & $1436.113^{\mathrm{a}}$ & $64.908^{\mathrm{a}}$ \\
& $(0.000)$ & $(0.000)$ \\
\hline
\end{tabular}

Notes: ${ }^{\mathrm{a}}$ and $^{\mathrm{c}}$ denote $1 \%$ and $10 \%$ significance levels, respectively. We include 2 lags to test for crosssectional dependence in variables, and a constant term was included in regressions. 
As tabulated in Table 2, both the LM and bias-adjusted LM tests reject the null hypothesis of cross-sectional independence for the model and each variable at the $1 \%$ significance level, except for $O C_{i t}$, for which the null hypothesis is rejected at the $10 \%$ significance level in the case of the bias-adjusted LM test. Based on the presence of cross-sectional dependence, we proceeded to employ Pesaran's (2007) unit root test, which allows for cross-sectional dependence.

Table 3: Results of the Im et al. (2003) and Pesaran (2007) Unit Root Tests

\begin{tabular}{|c|c|c|c|c|c|c|c|c|}
\hline Lags & \multicolumn{2}{|c|}{ IPS t-statistic } & \multicolumn{2}{c|}{$\mathbf{p = 1}$} & \multicolumn{2}{c|}{$\mathbf{p = 2}$} & \multicolumn{2}{c|}{$\mathbf{p = 3}$} \\
\cline { 4 - 9 } Variables & \multicolumn{2}{|c|}{ CIPS statistic } & \multicolumn{2}{c|}{ CIPS statistic } & \multicolumn{2}{c|}{ CIPS statistic } \\
\cline { 2 - 8 } & Level & $\begin{array}{c}\text { First- } \\
\text { differences }\end{array}$ & Level & $\begin{array}{c}\text { First- } \\
\text { differences }\end{array}$ & Level & $\begin{array}{c}\text { First- } \\
\text { differences }\end{array}$ & Level & $\begin{array}{c}\text { First- } \\
\text { differences }\end{array}$ \\
\hline$O C_{i t}$ & -1.427 & $-4.603^{\mathrm{a}}$ & -1.713 & $-4.079^{\mathrm{a}}$ & -1.780 & $-3.874^{\mathrm{a}}$ & -1.799 & $-3.737^{\mathrm{a}}$ \\
\hline$O P_{i t}$ & -1.333 & $-5.637^{\mathrm{a}}$ & -2.086 & $-3.982^{\mathrm{a}}$ & -2.086 & $-3.982^{\mathrm{a}}$ & -2.014 & $-3.295^{\mathrm{a}}$ \\
\hline$Y_{i t}$ & -1.395 & $-3.620^{\mathrm{a}}$ & -2.052 & $-3.204^{\mathrm{a}}$ & -2.049 & $-3.204^{\mathrm{a}}$ & -1.941 & $-3.204^{\mathrm{a}}$ \\
\hline
\end{tabular}

Notes: We include the intercept as a deterministic component in regressions. In this case, the critical values for Pesaran's (2007) test are $-2.38,-2.20$, and -2.11 at the $1 \%, 5 \%$, and $10 \%$ significance levels, respectively. See Table 2(b) in Pesaran (2007). ${ }^{a}$ denotes rejection of the unit root null hypothesis at the $1 \%$ level of significance. We selected 1,2, and 3 lags as a maximum lag number to correct serial correlation in Pesaran (2007) test. Schwarz information criterion was used in the selection of lag length in the IPS test. The critical values for the IPS test are $-1.99,-1.85$, and -1.78 at the $1 \%, 5 \%$, and $10 \%$ significance levels, respectively.

We also provided the results of the IPS test, for comparison purposes, along with the results of the Pesaran (2007) test. As seen in Table 3, all variables are nonstationary in their levels under both tests, but they are stationary in their firstdifferences. The unit root null hypothesis is rejected at the $1 \%$ significance level after taking first-differences of variables. Thus, it can be concluded that all variables are integrated of order one, i.e. I (1).

\subsection{Results of Slope Homogeneity and Cointegration Tests}

Having established that all variables are integrated of order 1 , as a next step we examined the presence of the long-run relationship between variables as in the order specified in Eq. (1). To this end, we implemented the $\mathrm{DHg}$ test of Westerlund $(2008)$ based on the presence of cross-sectional dependence and slope heterogeneity, and the results are provided in Table 4.

As shown in Table $4, \tilde{\Delta}$ and $\tilde{\Delta}_{a d j}$ tests provide evidence of slope heterogeneity at the $1 \%$ level of significance. Therefore, we proceeded to test for cointegration under the presence of slope heterogeneity and cross-sectional dependence (Ozcan, 2013). To this end, we implemented the $\mathbf{D H}_{g}$ test, but for comparison purposes we also provided the result of the $\mathbf{D H}_{p}$ test. The null hypothesis of no- 
cointegration is rejected at the $1 \%$ level of significance in both tests. ${ }^{4}$ It can therefore be inferred that there is a cointegration for at least some panel members.

Table 4: Results of Slope Homogeneity and Cointegration Tests

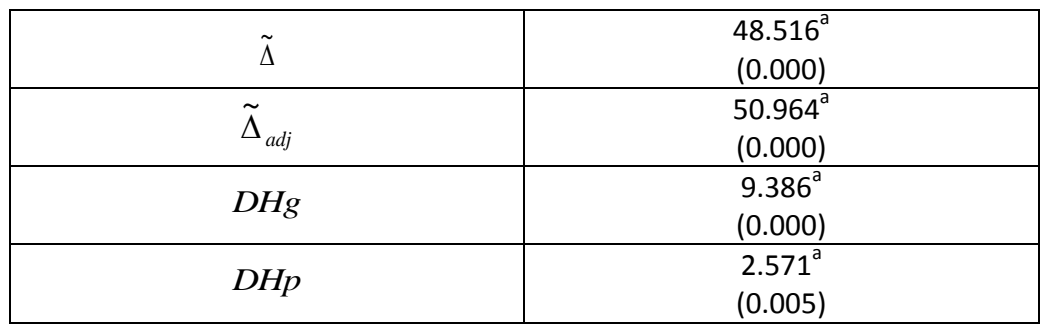

Notes: Probabilities are reported in parentheses. For the Westerlund (2008) cointegration test, the criterion used in this paper is IC $\mathrm{C}_{2}(\mathrm{~K})$ with the maximum number of factors $(K)$ set equal to three. For the bandwidth selection, $M$ was chosen to the largest integer less than $4(T / 100)^{2 / 9}$ as suggested by Newey and West (1994). ${ }^{a}$ indicates the rejection of slope homogeneity null hypothesis in Delta tests and the null hypothesis of no cointegration in the Westerlund (2008) test at the $1 \%$ level of significance.

\subsection{Estimation of Long-Run Parameters}

The results of the FMOLS estimation for each country and the whole panel set are presented in Table 5. The price and income elasticities of demand for oil measure the responsiveness or sensitivity of oil demand to changes in price and income levels. With respect to country-based results, for twelve countries-namely Denmark, France, Germany, Ireland, Italy, Japan, Portugal, Spain, Sweden, Switzerland, Turkey, and the United States-positive and significant income elasticity coefficients were obtained. For 10 out of these 12 countries (all but Ireland and Japan), oil demand is highly income-elastic, since a $1 \%$ percent increase in GDP per capita leads to more than a $1 \%$ increase in their oil consumption per capita levels. In addition, it could be stated that oil is a normal but luxury good for these 10 countries. For Ireland and Japan, however, oil appears to be a normal but necessary good, since their income elasticity coefficients are positive but below one. For Belgium and the UK, oil seems to be an inferior good, since increases in GDP per capita levels in those countries cause decreases in their oil consumption per capita levels. For instance, a 1\% percent increase in GDP per capita reduces oil consumption per capita by $1.16 \%$ in the UK. Webb (2006) called this case the dematerialization theory. According to this theory, inputs such as energy used in each unit of output produced decrease while income increases, since there is a move away from heavy industry toward light industry.

\footnotetext{
${ }^{4}$ We also employed the LM-bootstrap cointegration test developed by Westerlund and Edgerton (2007) and obtained the cointegration result. The reported LM-statistic was 3.014 with 0.549 bootstrap probability value, indicating that the cointegration null hypothesis cannot be rejected.
} 
Table 5: Results of FMOLS

\begin{tabular}{|c|c|c|c|c|c|}
\hline Country & $O P_{i t}$ & $Y_{i t}$ & Country & $O P_{i t}$ & $Y_{i t}$ \\
\hline Austria & $\begin{array}{c}-0.04 \\
(-0.14)\end{array}$ & $\begin{array}{c}-0.38 \\
(-0.33)\end{array}$ & Japan & $\begin{array}{c}-0.04 \\
(-0.77)\end{array}$ & $\begin{array}{l}0.84^{\mathrm{a}} \\
(6.69)\end{array}$ \\
\hline Belgium & $\begin{array}{l}-1.10^{\mathrm{a}} \\
(-3.17)\end{array}$ & $\begin{array}{l}-3.35^{\mathrm{a}} \\
(-5.20)\end{array}$ & Netherlands & $\begin{array}{c}-0.88 \\
(-1.35)\end{array}$ & $\begin{array}{c}0.55 \\
(0.37) \\
\end{array}$ \\
\hline Canada & $\begin{array}{c}0.06 \\
(0.33) \\
\end{array}$ & $\begin{array}{c}0.66 \\
(1.47) \\
\end{array}$ & Norway & $\begin{array}{l}-1.16^{b} \\
(-2.18)\end{array}$ & $\begin{array}{c}0.59 \\
(1.29)\end{array}$ \\
\hline Denmark & $\begin{array}{c}0.43 \\
(1.17)\end{array}$ & $\begin{array}{l}2.03^{\mathrm{a}} \\
(4.10)\end{array}$ & Portugal & $\begin{array}{l}-0.41^{b} \\
(-2.28)\end{array}$ & $\begin{array}{l}1.41^{\mathrm{a}} \\
(3.62)\end{array}$ \\
\hline Finland & $\begin{array}{l}-0.62^{\mathrm{a}} \\
(-4.51)\end{array}$ & $\begin{array}{c}0.18 \\
(0.65) \\
\end{array}$ & Spain & $\begin{array}{l}0.74^{b} \\
(2.13)\end{array}$ & $\begin{array}{l}3.49^{\mathrm{a}} \\
(4.52)\end{array}$ \\
\hline France & $\begin{array}{c}0.16 \\
(1.30)\end{array}$ & $\begin{array}{c}1.50^{\mathrm{a}} \\
(20.81)\end{array}$ & Sweden & $\begin{array}{l}-1.01^{\mathrm{a}} \\
(-6.33)\end{array}$ & $\begin{array}{l}1.45^{\mathrm{a}} \\
(3.72)\end{array}$ \\
\hline Germany & $\begin{array}{l}-0.32^{a} \\
(-5.82)\end{array}$ & $\begin{array}{l}1.36^{\mathrm{a}} \\
(8.77)\end{array}$ & Switzerland & $\begin{array}{c}-0.05 \\
(-0.32)\end{array}$ & $\begin{array}{l}1.06^{\mathrm{a}} \\
(9.73)\end{array}$ \\
\hline Iceland & $\begin{array}{c}0.36 \\
(1.36)\end{array}$ & $\begin{array}{c}-0.71 \\
(-1.39)\end{array}$ & Turkey & $\begin{array}{c}0.14 \\
(1.06)\end{array}$ & $\begin{array}{l}1.15^{\mathrm{a}} \\
(2.94)\end{array}$ \\
\hline Ireland & $\begin{array}{c}0.25 \\
(0.94) \\
\end{array}$ & $\begin{array}{c}0.84^{a} \\
(14.46)\end{array}$ & UK & $\begin{array}{c}0.24^{\mathrm{c}} \\
(1.78) \\
\end{array}$ & $\begin{array}{l}-1.16^{\mathrm{a}} \\
(-4.64) \\
\end{array}$ \\
\hline \multirow[t]{2}{*}{ Italy } & $\begin{array}{c}0.02 \\
(0.24)\end{array}$ & $\begin{array}{c}1.43^{\mathrm{a}} \\
(23.32)\end{array}$ & USA & $\begin{array}{c}-0.04 \\
(-0.34)\end{array}$ & $\begin{array}{l}1.54^{\mathrm{c}} \\
(1.67)\end{array}$ \\
\hline & & & Panel & $\begin{array}{l}-0.16^{\mathrm{a}} \\
(-3.77)\end{array}$ & $\begin{array}{c}0.72^{\mathrm{a}} \\
(21.60)\end{array}$ \\
\hline
\end{tabular}

Notes: ${ }^{\mathrm{a}}, \mathrm{b},{ }^{\mathrm{c}}$ indicate significance at the $1 \%, 5 \%$, and $10 \%$ levels; t-statistics are reported in parentheses.

Finally, for the six remaining countries-namely, Austria, Canada, Finland, Iceland, the Netherlands, and Norway-income elasticity coefficients are insignificant. In other words, for these six countries, income has no significant impact on oil consumption.

With regard to price elasticity of oil consumption, only six countries-namely, Belgium, Finland, Germany, Norway, Portugal, and Sweden - have expected significant and negative price elasticity coefficients. An increase in oil price reduces oil consumption per capita levels of these six countries. For Spain and the UK, however, an unexpected result was obtained, as they have significant positive price elasticity coefficients. For the other 12 countries, insignificant price elasticity coefficients were obtained. Therefore, it could be stated that oil price changes do not have any significant effects on oil consumption levels for most OECD countries under study. On the other side, insignificant price elasticities show that tax policies are not useful in curbing the demand; however, the taxation of oil imports may be a good source of revenue (Moore, 2011).

In terms of panel results, the coefficients of long-run income and oil price elasticities have the expected signs. Therefore, price and income elasticities go in line with economic theory. As such, a 1\% percent increase in GDP per capita level leads to about a $0.72 \%$ increase in oil consumption per capita level for the whole 
panel set, while a $1 \%$ increase in oil price decreases the demand for oil by $0.16 \%$ in the long-run. In the long-run, oil demand is both income and price-inelastic as obtained by many studies in the literature; however, income elasticity is higher than price elasticity (see, among others, Altinay 2007; Narayan and Smyth, 2007; Narayan and Wong, 2009; Behmiri and Manso, 2012). Based on the panel results, it could be asserted that crude oil demand is highly price-inelastic, indicating that consumers are insensitive to price changes. Furthermore, the price inelasticity for OECD countries indicates that rising oil prices in the future due to oil depletion will not secure the reduction of oil consumption and will result in extreme inflation (Cho et al., 2011). Therefore, despite its decreasing consumption level, oil is still an essential energy source for most OECD countries.

If we compare our results with those of Behmiri and Manso (2012), we obtain nearly identical results for the price elasticity of Austria ( -0.04 in both studies); income elasticity of Canada ( 0.61 in their study and 0.66 in this study); price elasticity of Finland ( -0.03 in their study, -0.62 in this study); income elasticity of France (2.5 in their study, 1.50 in this study); income and price elasticities of Germany (they found the income and price elasticities to be 1.55 and -0.09 , respectively, while we calculated these values to be 1.36 and -0.32 ); income elasticity of Italy (2.06 in their study, 1.43 in our study); income elasticity of Norway ( 0.38 in their study, 0.59 in our study); price elasticity of Switzerland ( -0.07 in their study, -0.05 in this study); and income and price elasticities of the United States (1.48 and -0.07 in their study, 1.54 and -0.04 in our study). Additionally, for income elasticity for the whole panel set, our result is in accordance with their results. We obtained long-run income elasticity to be 0.72 , while they found it to be 0.96 . There is a minor difference for long-run price elasticity; however, we obtained a more elastic price coefficient $(-0.16)$ than theirs $(-0.05)$. In Behmiri - Manso (2012), changes in long-run income elasticities range from -0.41 (not significant in Sweden) to 2.5 (in France), whereas long-run price elasticities fall within the range of -0.23 (South Korea) to +0.09 (Hungary and Netherlands). In our study, however, the long-run income elasticity of oil consumption ranges from -3.35 (in Belgium) to +3.49 (in Spain). The coefficients of long-run price elasticity range between -1.10 (in Belgium) and +0.74 (in Spain).

Another study by Cooper (2003) found that long-run price elasticity estimates were in the range of -0.56 (in France) to +0.03 (in Portugal). In addition, the results of long-run price elasticity of Germany $(-0.27)$ and Switzerland $(-0.05)$ are similar to ours. In Tsirimokos's (2011) study, the results of long-run income elasticity of Denmark (2.47), Spain (3.24), Italy (1.71), and Portugal (1.93) and the price elasticity of the United States $(-0.06)$ are in line with our results. The results of long-run price elasticities in his study, however, are in contrast with ours since his results indicated that long-run price elasticities fell between -0.275 to -0.066 , while long-run income elasticities ranged between 0.726 and 2.473 . 


\subsection{Results of Panel Causality Test}

The results of short- and long-run panel causality tests are presented in Table 6. With respect to Eq. (12a), economic growth has a significant and positive effect on oil consumption, whereas oil price has a negative but insignificant effect on oil consumption in the short-run. In other words, increases in oil price do not lead to decreases in oil consumption, as consumers are insensitive to oil price changes in the short-run.

\section{Table 6: Results of Panel Causality Test}

\begin{tabular}{|c|c|c|c|c|c|c|c|}
\hline \multirow{3}{*}{$\begin{array}{l}\text { Dependent } \\
\text { variable }\end{array}$} & \multicolumn{7}{|c|}{ Sources of causation (independent variables) } \\
\hline & \multicolumn{4}{|c|}{ Short-run } & \multicolumn{3}{|c|}{ Long-run } \\
\hline & \multicolumn{2}{|c|}{$\triangle O C$} & \multicolumn{2}{|c|}{$\Delta Y$} & \multicolumn{2}{|c|}{$\triangle O P$} & \multirow{2}{*}{$\begin{array}{c}\text { ECT } \\
-0.183^{\mathrm{a}}\end{array}$} \\
\hline \multirow{2}{*}{$\triangle O C$} & & & $25.34^{\mathrm{a}}$ & {$[0.435]^{\mathrm{a}}$} & 0.03 & {$[-0.006]$} & \\
\hline & & & $(0.000)$ & $(0.000)$ & (0.873) & $(0.874)$ & $(-4.169)$ \\
\hline \multirow{2}{*}{$\Delta Y$} & $15.42^{\mathrm{a}}$ & {$[0.094]^{a}$} & & & 1.28 & {$[-0.022]$} & $-0.654^{\mathrm{a}}$ \\
\hline & $(0.000)$ & $(0.000)$ & & & $(0.258)$ & $(0.258)$ & $(-2.57)$ \\
\hline \multirow{2}{*}{$\triangle O P$} & 0.13 & {$[0.025]$} & 0.20 & {$[-0.824]$} & & & $-0.248^{\mathrm{a}}$ \\
\hline & (0.719) & $(0.720)$ & $(0.651)$ & $(0.651)$ & & & $(-6.43)$ \\
\hline
\end{tabular}

Notes: Chi-squared statistics were reported with respect to short-run changes in the independent variables. The sum of lagged coefficients for the respective short-run changes is given in brackets. Lag length is selected as 1, based on the Schwarz information criterion. Probability values are in parentheses and reported underneath the corresponding $\chi^{2}$ statistics and the sum of lagged coefficients. T-statistics are reported in parentheses underneath the ECT terms, while ECT represents the coefficient of the errorcorrection term; ${ }^{\mathrm{a}}$ indicates significance at the $1 \%$ level.

In terms of Eq. (12b), there is a positive and significant impact of oil consumption on economic growth; oil price, however, does not significantly affect economic growth in the short-run. In the theoretical framework, a negative impact of oil price on economic growth is expected, as the share of oil demand payment in GDP will increase because of the higher oil price levels, which means the share of productive investment in GDP will decrease as a result of the budget constraint. Furthermore, higher oil price level may negatively affect the current account balance. To stabilize the volume of demand for imported oil, the import expenditure of government increases, which leads to decreases in GDP level. OECD countries, however, have started to reduce their dependence on imported oil demand and use alternative energy sources due to oil price shocks. If countries consume more alternative energy and less oil, oil price changes may not have an adverse impact on economic growth. Additionally, based on Eqs. (12a) and (12b), we can confirm the feedback hypothesis for the oil consumption-economic growth nexus, as there is a bidirectional relationship between them. Finally, in the case of Eq. (12c), oil consumption and economic growth do not appear to have significant effects on oil price in the short-run. Nevertheless, increased oil consumption may lead to 
increases in oil prices in the long run due to depletion of oil reserves, whereas this effect may not appear in the short-run.

As regards the long-run relationships, Eqs. (12a)-(12c) indicate that oil consumption, economic growth, and oil price respond to deviations from long-run equilibrium, as their error-correction terms are statistically significant. In the case of Eq. (12a), there is a long-run relationship from oil price and economic growth to oil consumption; the long-run relationship is from the oil consumption and oil price to economic growth in the case of Eq. (12b). Finally, with regard to Eq. (12c), the long-run causality runs from oil consumption and economic growth to oil price. Given the magnitude of the coefficients of the error terms, the speed of adjustment toward the long-run is rather slow for oil consumption and oil price variables, whereas it is rather fast for per capita GDP. The statistical significance of the error-correction terms suggests that oil consumption, per capita GDP, and oil price respond to deviations from long-run equilibrium with an adjustment of roughly 5.46, 1.52, and 4.03 years, respectively.

In summary, the feedback hypothesis is confirmed in both the short-run and the long-run. This means that an increase in oil consumption directly affects economic growth and that economic growth also stimulates further oil consumption. In other words, there is a complementary relationship between oil demand and economic growth. Oil conservation policies and reduction of oil consumption negatively affect economic growth; besides, decreases in economic growth rates have negative effects on oil demand as well.

Additionally, we can compare our causality test results with those of other studies examining oil or different energy sources-economic growth nexus in OECD countries. For instance, among others, the feedback hypothesis is also supported by Behmiri and Manso (2012) for the oil-growth nexus in 27 OECD countries, Lee Lee (2010) for the total energy demand-growth nexus in 25 OECD countries; Apergis and Payne (2010a) for the renewable energy-growth nexus in 20 OECD countries, and Apergis and Payne (2010b) for the nuclear energy-growth nexus in 16 OECD countries. In addition, there are studies that found evidence of the feedback hypothesis in non-OECD countries, such as Apergis and Payne (2013) for the electricity consumption-growth nexus in South America, Apergis and Payne (2012) for the renewable energy-growth nexus in 80 countries, and Lim and Yoo (2011) for the natural gas consumption-growth nexus in Korea.

\section{Conclusion and Policy Implications}

Most developed countries try to reduce their oil consumption levels as part of their eco-friendly energy policy agendas by looking for alternative energy sources such as renewable and nuclear energy. In addition, the high level of greenhouse gases (GHG) emissions rates and depletion of oil reserves worldwide necessitate this effort. However, due to rapid urbanization and improved living standards, oil is still 
essential in supporting day-to-day activities, especially in developing countries (Stambuli, 2013). Additionally, despite its diminishing market share since the 1970s, oil is still the world's dominant fuel, with a rate of $33 \%$ of current global primary energy consumption (Finley, 2012). Therefore, it is crucial to evaluate the determinants of oil demand. Additionally, as stated by Lee and Lee (2010), accurate and reliable estimates of income and price elasticities of demand for oil provide important information for governments and energy companies as they formulate policies to restructure the energy sector and upgrade energy demand policies.

Based on the abovementioned explanations, we examined the long-run determinants of oil demand (i.e., its long-run income and price elasticities for 20 OECD countries in the framework of panel data model). Among the country-based results, significant and positive income elasticity coefficients were obtained for 12 countries, whereas only for six countries the price elasticity coefficients appeared to be negative and significant. In addition, the panel results indicate that both longrun income and price elasticities are significant and that they are positive and negative, respectively. Income elasticity is higher than price elasticity, but both are inelastic, as they are smaller than one. As stated by Cho et al. (2011), the price inelasticity for OECD countries indicates that a rising oil price in the future due to oil depletion will not reduce oil consumption and result in extreme inflation. Furthermore, as income growth leads to additional oil consumption, economic growth will be accompanied by higher oil consumption, which will put upward pressure on oil prices due to depleting oil reserves; thus, there are likely to be monetary policy implications for rising oil prices (Narayan and Wong 2009). Furthermore, the implementation of pricing policies to curtail energy demand may not be useful, due to the relatively low magnitude of price elasticity. Also, as stated by Pedregal et al. (2009), the low price elasticity of oil demand signals that governments should find new mechanisms to modify consumption patterns by spreading technological or environmental information to affect individuals' consumption decisions or by subsidizing the installation of more energy-efficient technologies.

We further examined the causality between variables of interest and confirmed the feedback hypothesis. In other words, there is a bidirectional causality running from economic growth to oil consumption and vice versa. As such, economic growth and oil consumption complement and reinforce each other, and oil conservation policies have adverse effects on economic growth. Hence, policies aimed at reducing oil consumption to curb the level of carbon emissions and protect the environment may not be implemented without adverse effects on economic growth.

\section{References}

Al-Faris, A.R. (1996/3) "Demand for Oil Products in the GCC Countries." The Economic Research Forum (ERF). 
Altinay, G. (2007) "Short-run and long-run elasticities of import demand for crude oil in Turkey." Energy Policy 35(11): 5829-5835. http://dx.doi.org/10.1016/j.enpol.2007.07.015

Al-Yousef, N. (2013) "Demand for Oil Products in OPEC Countries: A Panel Cointegration Analysis." International Journal of Energy Economics and Policy 3(2): 168-177.

Apergis, N. \& Payne J.E. (2010a) "Renewable energy consumption and economic growth: Evidence from a panel of OECD countries." Energy Policy 38(1): 656-660. http://dx.doi.org/10.1016/j.enpol.2009.09.002

Apergis, N. \& Payne J.E. (2010b) "A panel study of nuclear energy consumption and economic growth." Energy Economics 32(3): 545-549. http://dx.doi.org/10.1016/j.eneco.2009.09.015

Apergis, N. \& Payne J.E. (2012) "A Global Perspective on the Renewable Energy ConsumptionGrowth Nexus." Energy Sources, Part B: Economics, Planning, and Policy 7(3): http://dx.doi.org/10.1080/15567249.2011.601530

Apergis, N. \& Payne J.E. (2013) "Another Look at the Electricity Consumption-Growth Nexus in South America." Energy Sources, Part B: Economics, Planning, and Policy 8(2): 171-178. http://dx.doi.org/10.1080/15567249.2011.653474

Arellano, M. \& Bond S. (1991) "Some Tests of Specification for Panel Data: Monte Carlo Evidence and an Application to Employment Equations." The Review of Economic Studies 58(2):

277-297.

http://dx.doi.org/10.2307/2297968

Behmiri, N.B. \& Manso J.R.P. (2012) "Crude oil conservation policy hypothesis in OECD (organisation for economic cooperation and development) countries: A multivariate panel Granger causality test." http://dx.doi.org/10.1016/j.energy.2012.04.032

Bilgili, F. (2014) "Long Run Elasticities of Demand for Natural Gas: OECD Panel Data Evidence." Energy Sources, Part B: Economics, Planning, and Policy 9(4): 334-341. http://dx.doi.org/10.1080/15567249.2010.497793

Breusch, T.S. \& Pagan, A.R. (1980) "The Lagrange Multiplier Test and its Applications to Model Specification in Econometrics." The Review of Economic Studies 47(1): 239-253. http://dx.doi.org/10.2307/2297111

British Petroleum Statistical Review of World Energy (2014). http://www.bp.com/content/dam/bp/pdf/Energy-economics/statistical-review2014/BP-

statistical-review-of-world-energy-2014-full-report.pdf. (accessed March10, 2014)

British Petroleum (BP) (2012) Energy Outlook 2030. London: British Petroleum.

Cho, C.H., Chu Y.P. \& Yang H.Y. (2011) "Oil demand and energy security in Asian countries." Journal of Energy Markets 4(2): 27-42.

Cooper, J.C.B. (2003) "Price elasticity of demand for crude oil: estimates for 23 countries." OPEC Review 27(1): 1-8.http://dx.doi.org/10.1111/1468-0076.00121

Dahl, C. (1994) "A survey of oil product demand elasticities for developing countries." OPEC Review 18(1): 47-86.http://dx.doi.org/10.1111/j.1468-0076.1994.tb00493.x

Dargay, J.M. (1992) "Are price and income elasticities of demand constant? : The UK experience." Oxford Institute for Energy Studies / EE, Energy economics, Oxford.

Dées, S., Karadeloglou P., Kaufmann R.K. \& Sanchez M. (2007) "Modelling the world oil market: Assessment of a quarterly econometric model." Energy Policy 35(1): 178-191. doi:10.1016/j.enpol.2005.10.017http://dx.doi.org/10.1016/j.enpol.2005.10.017

De Vita, G., Endresen K. \& Hunt L.C. (2006) "An empirical analysis of energy demand in 
Namibia." Energy Policy 34(18): 3447-3463. http://dx.doi.org/10.1016/j.enpol.2005.07.016

Dickey, D.A. \& Fuller W.A. (1979) "Distribution of the Estimators for Autoregressive Time Series with a Unit Root." Journal of the American Statistical Association 74(366a): 427-431. http://dx.doi.org/10.2307/2286348

Engle, R.F. \& Granger C.W.J. (1987) "Co-Integration and Error Correction: Representation, Estimation, and Testing." Econometrica 55(2): 251-276.http://dx.doi.org/10.2307/1913236

Farinelli, B., Carter C.A., Lin C.Y.C. \& Summer D.A. (2009) "Import Demand for Brazilian Ethanol: A Cross-Country Analysis." Journal of Cleaner Production 17: 9-17. http://dx.doi.org/10.1016/j.jclepro.2009.05.008

Fawcett, N. \& Price S. (2012) "World Oil Demand In A Cross-Country Panel. Meeting of the European Economic Association 2012." http://www.eea-esem.com/files/papers/eeaesem/2012/2340/Oil-elasticities.pdf. (accessed June 20, 2014).

Feenstra, R.C., Inklaar R. \& Timmer M.P. (2013) "The Next Generation of the Penn World Table." NBER Working Paper 19255.

Finley, M. (2012) "The Oil Market to 2030-Implications for Investment and Policy." Economics of Energy \& Environmental Policy 1(1): 25-36.http://dx.doi.org/10.5547/21605890.1.1.4

Filippini, M. (2011) "Short- and long-run time-of-use price elasticities in Swiss residential electricity demand." Energy Policy 39(10): http://dx.doi.org/10.1016/j.enpol.2011.06.002

Fournier, J.M., Koske I., Wanner I. \& Zipperer V. (2013) "The Price Of Oil - Will It Start Rising Again?" Organisation for Economic Co-operation and Development (OECD). http://dx.doi.org/10.1787/5k49q186vxnp-en

Gately, D. \& Huntington H.G. (2002) "The Asymmetric Effects of Changes in Price and Income on Energy and Oil Demand." Energy Journal 23(1): 19-55. http://dx.doi.org/10.5547/ISSN0195-6574-EJ-Vol23-No1-2

Ghosh, S. (2009) "Import demand of crude oil and economic growth: Evidence from India." Energy Policy 37(2): 699-702.

Ghouri, S.S. (2001) "Oil demand in North America: 1980-2020." OPEC Review 25(4): 339-355. http://dx.doi.org/10.1111/1468-0076.00103

Halicioglu, F. (2007) "Residential electricity demand dynamics in Turkey." Energy Economics 29(2): 199-210. http://dx.doi.org/10.1016/j.eneco.2006.11.007

Im, K.S., Pesaran M.H. \& Shin Y. (2003) "Testing for unit roots in heterogeneous panels." Journal of Econometrics 115(1): 53-74. http://dx.doi.org/10.1016/S0304-4076(03)00092-7

International Energy Agency (IEA) (2013) "World Energy Outlook 2013 - Executive Summary." France: IEA

International Financial Statistics (IFS) (2014).

Iwayemi, A., Adenikinju A. \& Babatunde M.A. (2010) "Estimating petroleum products demand elasticities in Nigeria: A multivariate cointegration approach." Energy Economics 32(1):73-85. http://dx.doi.org/10.1016/j.eneco.2009.05.002

Krichene, N. (2002) "World crude oil and natural gas: a demand and supply model." Energy Economics 24(6): 557-576.http://dx.doi.org/10.1016/S0140-9883(02)00061-0

Krichene, N. (2005) "A Simultaneous Equations Model for World Crude Oil and Natural Gas Markets." IMF Working Paper 05/32. http://dx.doi.org/10.5089/9781451860511.001 
Lee, C.C. \& Lee J.D. (2010) "A Panel Data Analysis of the Demand for Total Energy and Electricity in OECD Countries." The Energy Journal 31(1):1-24. http://dx.doi.org/10.5547/ISSN0195-6574-EJ-Vol31-No1-1

Lee, C.C. \& Chiu Y.B. (2013) "Modeling OECD energy demand: An international panel smooth transition error-correction model." International Review of Economics \& Finance 25: 372383. http://dx.doi.org/10.1016/j.iref.2012.08.002

Lim, H.J. \& Yoo S.H. (2011) "Natural Gas Consumption and Economic Growth in Korea: A Causality Analysis." Energy Sources, Part B: Economics, Planning, and Policy 7(2): 169-176. http://dx.doi.org/10.1080/15567240902882864

Moore, A. (2011) "Demand elasticity of oil in Barbados." Energy Policy 39(6): 3515-3519. http://dx.doi.org/10.1016/j.enpol.2011.03.050

Narayan, P.K. \& Smyth R. (2005) "The residential demand for electricity in Australia: an application of the bounds testing approach to cointegration." Energy Policy 33(4): 467-474. http://dx.doi.org/10.1016/j.enpol.2003.08.011

Narayan, P.K. \& Smyth R. (2007) "A panel cointegration analysis of the demand for oil in the Middle East." Energy Policy 35(12): 6258-6265. http://dx.doi.org/10.1016/j.enpol.2007.07.011

Narayan, P.K., Smyth R. \& Prasad A. (2007) "Electricity consumption in G7 countries: A panel cointegration analysis of residential demand elasticities." Energy Policy 35(9): 4485-4494. http://dx.doi.org/10.1016/j.enpol.2007.03.018

Narayan, P.K. \& Wong P. (2009) "A panel data analysis of the determinants of oil consumption: The case of Australia." Applied Energy 86(12):2771-2775. http://dx.doi.org/10.1016/j.apenergy.2009.04.035

Newey, W.K. \& West K.D. (1994) "Automatic Lag Selection in Covariance Matrix Estimation." The Review of Economic Studies 61(4): 631-653. http://dx.doi.org/10.2307/2297912

OECD (2012). OECD Enviornmental Outlook to 2050: The Consequences of Inaction.

Ozcan, B. (2013) "The nexus between carbon emissions, energy consumption and economic growth in Middle East countries: A panel data analysis." Energy Policy 62: 1138-1147. http://dx.doi.org/10.1016/j.enpol.2013.07.016

Pedregal, D.J., Dejuán O., Gómez N. \& Tobarra M.A. (2009) "Modelling demand for crude oil products in Spain." Energy Policy 37(11): 4417-4427. http://dx.doi.org/10.1016/j.enpol.2009.05.062

Pedroni, P. (2001a) "Fully modified OLS for heterogeneous cointegrated panels." Advances in Econometrics 15: 93-130.http://dx.doi.org/10.1016/S0731-9053(00)15004-2

Pedroni, P. (2001b) "Purchasing Power Parity Tests in Cointegrated Panels." Review of Economics and Statistics 83(4): 727-731.http://dx.doi.org/10.1162/003465301753237803

Pesaran, M.H. (2007) "A simple panel unit root test in the presence of cross-section dependence." Journal of Applied Econometrics 22(2): 265-312. http://dx.doi.org/10.1002/jae.951

Pesaran, M.H., Shin Y. \& Smith R.P. (1999) "Pooled Mean Group Estimation of Dynamic Heterogeneous Panels." Journal of the American Statistical Association 94(446): 621-634. http://dx.doi.org/10.1080/01621459.1999.10474156

Pesaran, M.H., Shin Y. \& Smith R.J. (2001) "Bounds testing approaches to the analysis of level relationships." Journal of Applied Econometrics 16(3): 289-326. 
http://dx.doi.org/10.1002/jae.616

Pesaran, H.M. \& Yamagata T. (2008) "Testing slope homogeneity in large panels." Journal of Econometrics 142(1): 50-93. http://dx.doi.org/10.1016/j.jeconom.2007.05.010

Pesaran, M.H., Ullah A. \& Yamagata T. (2008) "A bias-adjusted LM test of error cross-section independence." Econometrics Journal 11(1): 105-127. http://dx.doi.org/10.1111/j.1368423X.2007.00227.x

Pindyck, R. (1979) The Structure of World Energy Demand. Cambridge: MIT Press.

Sa'ad, S. (2009) "An empirical analysis of petroleum demand for Indonesia: An application of the cointegration approach." Energy Policy 37(11):4391-4396. http://dx.doi.org/10.1016/j.enpol.2009.05.058

Salim, R.A., Hassan K. \& Shafiei S. (2014) "Renewable and non-renewable energy consumption and economic activities: Further evidence from OECD countries." Energy Economics 44(0): 350-360. http://dx.doi.org/10.1016/j.eneco.2014.05.001

Sillah, B.M.S. \& Al-Sheikh H.M.H. (2012) "Income, Price, and Government Expenditure Elasticities of Oil in the Gulf Cooperation Council Countries." International Journal of Energy Economics and Policy 2(4): 333-341.

Stambuli, B.B. (2013) "Price and Income Elasticities of Oil Demand in Tanzania: An Autoregressive Approach. Business and Management Dynamics." 3(1): 75-83.

Swamy, P.A.V.B. (1970) "Efficient Inference in a Random Coefficient Regression Model." Econometrica 38(2): 311-323.http://dx.doi.org/10.2307/1913012

Tiwari, A.K., Shahbaz M. \& Shahbaz S.M. (2012) "Is Per Capita GDP Non-linear Stationary in SAARC Countries?" European Economic Letters 1(1): 1-5.

Tsirimokos, C. (2011) "Price and Income Elasticities of Crude Oil Demand." in Department of Economics. Swedish University of Agricultural Sciences: Uppsala.

Webb, M. (2006) "Analysis of Oil Consumption with Dynamic Panel Data Models." http://www.commerce.otago.ac.nz/ECON/events/Papers/S4_Webb.pdf] (accessed August 23, 2014).

Westerlund, J. \& Edgerton D.L. (2007) "A panel bootstrap cointegration test." Economics Letters 97(3): 185-190. http://dx.doi.org/10.1016/j.econlet.2007.03.003

Westerlund, J. (2008) "Panel cointegration tests of the Fisher effect." Journal of Applied Econometrics 23(2): 193-233. http://dx.doi.org/10.1002/jae.967

World Bank (2014). World Development Indicators. http://data.worldbank.org/datacatalog/world-development-indicators (accessed August 06, 2014).

World Energy Council. World Energy Insight 2013. http://www.worldpetroleum.org/docs/docs/publications/wpc\%2080th\%201.pdf. (accessed August 21, 2014).

World Petroleum. (2013). World Petroleum Council: Addressing Global Energy Challenges.

Ziramba, E. (2010) "Price and income elasticities of crude oil import demand in South Africa:

A cointegration analysis." Energy Policy 38(12): 7844-7849. http://dx.doi.org/10.1016/j.enpol.2010.08.044 